\title{
KUALITAS SILASE TEBON JAGUNG (Zea mays L.) DENGAN PENAMBAHAN BERBAGAI BAHAN ADITIF DITINJAU DARI KANDUNGAN NUTRISI
}

\author{
Nutrient Content of Maize Stover Silage (Zea mays) with Variuos Additives \\ Lisa Mufida Mustika ${ }^{1}$, Hartutik $^{2)}$ \\ ${ }^{1)}$ Mahasiswa Fakultas Peternakan, Universitas Brawijaya Jalan Veteran, Ketawanggede, Kec. Lowokwaru, Kota \\ Malang, Jawa Timur, Indonesia 65145 \\ ${ }^{2)}$ Dosen Fakultas Peternakan, Universitas Brawijaya Jalan Veteran, Ketawanggede, Kec. Lowokwaru, Kota \\ Malang, Jawa Timur, Indonesia 65145 \\ Email: lisamufida5@gmail.com \\ Diterima Pasca Revisi: 22 Februari 2021 \\ Layak Diterbitkan: 1 Maret 2021
}

\begin{abstract}
ABSTRAK
Penelitian ini menggunakan berbagai aditif dalam proses pembuatan silase tebon jagung (Zea mays). Tujuan penelitian ini adalah mengevaluasi penggunaan bahan aditif terhadap kandungan nutrisi silase tebon jagung. Bahan yang digunakan adalah tebon jagung, bekatul, pollard, molases, dan tepung gaplek. Metode penelitian yang digunakan adalah uji laboratorium dengan menggunakan Rancangan Acak Lengkap (RAL) tersarang yang terdiri dari dua faktor yaitu jenis bahan aditif yang digunakan dan level penggunaannya dalam pembuatan silase. Variabel penelitian terdiri dari kandungan nutrisi meliputi Bahan Kering (BK), Bahan Organik (BO), dan Protein Kasar (PK). Data dianalisis dengan analisis ragam dan apabila terdapat perbedaan yang signifikan dilanjutkan analisis Uji Jarak Berganda Duncan (UJBD). Hasil penelitian menunjukkan bahwa penambahan bahan aditif yaitu bekatul, pollard, molases, dan tepung gaplek mampu meningkatkan kualitas silase tebon jagung, namun perlakuan yang terbaik adalah penggunaan pollard dengan level optimal $10 \%$.
\end{abstract}

Kata kunci: Aditif, kandungan nutrisi, silase, tebon jagung,

How to Cite:

Mustika, L. M., \& Hartutik. (2021). Kualitas Silase Tebon Jagung (Zea mays L.) dengan Penambahan Berbagai Bahan Aditif Ditinjau dari Kandungan Nutrisi. Jurnal Nutrisi Ternak Tropis 4 (1) 55-59
*Corresponding author:

Lisa Mufida Mustika

Email: lisamufida5@gmail.com

Fakultas Peternakan, Universitas Brawijaya Jalan

Veteran, Ketawanggede, Kec. Lowokwaru, Kota Malang, Jawa Timur, Indonesia 65145 


\begin{abstract}
This research used various additives in the ensiling of maize stover silage (Zea mays). This study aimed to evaluate the use of additives on the nutritional content of corn sugarcane silage. The additives materials used are corn sugarcane, bran, pollard, molasses, and cassava flour. The research method used is a laboratory test using a completely randomized design (CRD) nested, which consists of two factors: the type of additive used and the level of use in making silage. The research variables consisted of nutritional content such as dry matter (DM), organic matter $(O M)$, and crude protein $(C P)$. The data were analyzed using variance analysis, and if there were significant differences, it was continued based on Duncan's Multiple Range Test. Based on the results of this study, it can be concluded that the addition of different additives tends to increase the silage of maize stover nutrient. The addition of additives, namely bran, pollard, molasses, and cassava flour, increased the quality of maize stover silage, but the best treatment is the use of pollard with an optimal level of 10\%.
\end{abstract}

Keywords: Additive, maize stover, nutrient content, silage

\section{PENDAHULUAN}

Kekurangan hijauan pada musim kemarau akan terjadi dan pada musim penghujan ketersediannya melimpah. Karakteristik pakan hijauan mudah rusak karena kadar airnya tinggi sehingga walaupun ketersediaannya melimpah namun tidak dapat disimpan tanpa ada perlakuan. Berdasarkan hal tersebut maka perlu ada metode untuk mengatasi kekurangan hijauan pada musim kemarau dan kelebihan saat musim penghujan Hartutik (2012). Hanafi (2008) menyatakan bahwa teknik pengawetan hijauan (silase) merupakan bagian dari sistem produksi ternak. Silase adalah metode pengawetan hijauan dengan cara fermentasi anaerob di dalam silo dengan kondisi kandungan air tinggi (60-70\%) dan dalam suasana asam. Selain manfaat silase untuk mengawetkan, silase juga bermanfaat untuk meningkatkan daya cerna selama proses fermentasi. Fermentasi merupakan proses perombakan dari struktur keras secara fisik, kimia, dan biologis sehingga bahan dari struktur kompleks menjadi sederhana dan daya cerna pakan akan menjadi lebih efisien. Bahan aditif berupa water soluble carbohydrate (WSC) bisa ditambahkan pada proses pembuatan silase dengan tujuan mempercepat ensilase. Keberhasilan pada pembuatan silase dipengaruhi oleh kandungan WSC, kadar air hijauan yang digunakan, jumlah bakteri asam laktat (BAL), dan kadar oksigen. Apabila saat ensilase berlangsung, terjadi kekurangan WSC, maka dapat menyebabkan BAL kekurangan asupan energi untuk pertumbahnnya, sehingga dapat menyebabkan kandungan asam laktat menjadi rendah dan penurunan $\mathrm{pH}$ yang lambat. Maka, untuk menjamin ketersedian kandungan WSC yang baik untuk keberhasilan proses ensilase perlu dilakukan penambahan bahan aditif (Jasin, 2015). Penelitian ini menggunakan tebon jagung sebagai bahan baku pembuatan silase yang merupakan bagian dari tanaman jagung meliputi batang, daun dan buah jagung muda yang umurnya dipanen pada umur tanaman 45 - 65 hari (Soeharsono dan Sudaryanto, 2006). Bahan aditif berupa sumber WSC akan ditambahkan untuk pembuatan silase terdiri dari bekatul, pollard, molases, dan tepung gaplek dan diharapkan mampu meningkatkan kandungan nutrisi dari silase tebon jagung. 


\section{MATERI DAN METODE}

\section{Materi Penelitian}

Materi penelitian yang digunakan dalam penelitian ini terdiri dari:

1. Bahan pembuatan silase terdiri dari :

a. Bahan baku: tebon jagung dengan jenis hibrida yang diperoleh dari Kecamatan
Karangploso, Malang dengan umur potong 65 hari sebanyak $2 \mathrm{~kg}$ per perlakuan.

b. Bahan aditif : pollard, molases, bekatul dan tepung gaplek diperoleh dari toko bahan pakan di Kecamatan Karangploso, Malang. Kandungan nutrisi bahan penyusun silase tebon jagung disajikan dalam Tabel 1.

Tabel 1. Hasil analisis proksimat bahan penyusun silase tebon jagung

\begin{tabular}{lccccccc}
\hline \multirow{2}{*}{ Perlakuan } & & \multicolumn{6}{c}{ Kandungan nutrien (\%BK) * } \\
\cline { 3 - 8 } & BK (\%) & BO (\%) & Abu (\%) & PK (\%) & SK (\%) & LK (\%) & BETN \\
\hline a.Tebon jagung & 31,2 & 80,3 & 7,43 & 7,8 & 23,55 & 2,34 & 55,66 \\
b. Pollard & 88,17 & 95,22 & 5,22 & 13,16 & 7,66 & 4,57 & 65,88 \\
c. Molases & 64,12 & 85,66 & 6,22 & 1,29 & 0,25 & 4,69 & 52,33 \\
d.Bekatul & 90,87 & 89,22 & 5,66 & 9,69 & 16,93 & 7,7 & 51,22 \\
e.Tepung gaplek & 87,56 & 84,33 & 5,44 & 3,61 & 4,18 & 1,57 & 50,23 \\
\hline
\end{tabular}

Keterangan:*) Berdasarkan 100\% BK *) Hasil Analisis Laboratorium Nutrisi dan Makanan Ternak Fakultas Peternakan Universitas Brawijaya

2. Peralatan yang digunakan pembuatan silase antara lain: mesin pencacah (chopper), sabit, sekop, toples, tali rafia, lakban, timbangan digital.

Pembuatan silase dilaksanakan di Laboratorium Lapang Sumber Sekar, Fakultas Peternakan Universitas Brawijaya, Malang, Jawa Timur. Analisis proksimat dilakukan di Laboratorium Nutrisi dan Makanan Ternak, Fakultas Peternakan, Universitas Brawijaya, Malang, Jawa Timur.

\section{Metode Penelitian}

Penelitian ini menggunakan metode percobaan dalam Rancangan Acak Lengkap (RAL) pola Tersarang dengan melibatkan 2 faktor yaitu factor I empat jenis aditif (faktor I ; pollard, molases, bekatul, tepung gaplek) dan tiga level penggunaan aditif (dengan 3 kali ulangan, sehingga terdapat 36 unit percobaan. Adapun perlakuan yang dicobakan adalah:

$$
\begin{array}{ll}
\mathrm{P}_{\mathrm{p} 0} & =\text { Tebon jagung }+0 \% \text { pollard } \\
\mathrm{P}_{\mathrm{p} 10} & =\text { Tebon jagung }+10 \% \text { pollard } \\
\mathrm{P}_{\mathrm{p} 20} & =\text { Tebon jagung }+20 \% \text { pollard } \\
\mathrm{P}_{\mathrm{m} 0} & =\text { Tebon jagung }+0 \% \text { molases } \\
\mathrm{P}_{\mathrm{m} 10} & =\text { Tebon jagung }+10 \% \text { molases } \\
\mathrm{P}_{\mathrm{m} 20} & =\text { Tebon jagung }+20 \% \text { molases }
\end{array}
$$

$$
\begin{array}{ll}
\mathrm{P}_{\mathrm{b} 0} & =\text { Tebon jagung }+0 \% \text { bekatul } \\
\mathrm{P}_{\mathrm{b} 10} & =\text { Tebon jagung }+10 \% \text { bekatul } \\
\mathrm{P}_{\mathrm{b} 20} & =\text { Tebon jagung }+20 \% \text { bekatul } \\
\mathrm{P}_{\mathrm{tg} 0} & =\text { Tebon jagung }+0 \% \text { tepung gaplek } \\
\mathrm{P}_{\mathrm{tg} 10} & =\text { Tebon jagung }+10 \% \text { tepung } \\
& \text { gaplek } \\
\mathrm{P}_{\mathrm{tg} 20} & =\text { Tebon jagung }+20 \% \text { tepung } \\
& \text { gaplek }
\end{array}
$$

Sampel bahan baku silase dan sampel produk silase tebon jagung dianalisis menggunakan metode proksimat (AOAC, 2005).

\section{Analisis Data}

Data yang diperoleh dari hasil pengamatan dianalisa menggunakan ANOVA dengan Rancangan Acak Lengkap pola Tersarang (Sudarwati dkk., 2019). Hasil yang berbeda akan dilanjutkan dengan Uji Jarak Berganda Duncan's.

\section{HASIL DAN PEMBAHASAN}

Tabel 2 menunjukkan data hasil analisis kandungan nutrisi silase tebon jagung dengan penambahan berbagai aditif dan level penggunaannya sebelum ensilase (0 hari) dan setelah inkubasi (21 hari). Data dalam Tabel 2 menunjukkan peningkatan kadar BK silase tebon jagung dibandingkan 
dengan data sebelum ensilase. Meningkatnya kandungan BK silase bisa dipengaruhi oleh penambahan bahan aditif berupa sumber WSC. Santi dkk. (2011) melaporkan bahwa, dedak padi yang diberikan ke dalam silase menambah

kandungan bahan kering silase menjadi lebih tinggi antara 26,93\% - 34,42\%. Hasil penelitian Riswandi (2014) juga menunjukkan bahwa adanya penambahan kandaungan BK silase yang ditambahkan dedak halus.

Tabel 2. Kandungan nutrisi silase tebon jagung dengan penambahan bahan aditif

\begin{tabular}{|c|c|c|c|c|c|c|}
\hline \multirow[t]{2}{*}{ Perlakuan } & \multicolumn{3}{|c|}{ Kandungan Nutrisi 0 hari (\%BK) } & \multicolumn{3}{|c|}{ Kandungan Nutrisi 21 hari (\%BK) } \\
\hline & BK & $\mathrm{BO}$ & PK & BK & BO & PK \\
\hline \multicolumn{7}{|l|}{ Pollard } \\
\hline $\mathrm{P}_{\mathrm{p} 0}$ & $22,4 \pm 0,04$ & $83,7 \pm 0,58$ & $7,5 \pm 0,17$ & $32,0 \pm 1,55$ & $87,0 \pm 0,33$ & $8,8 \pm 0,17$ \\
\hline $\mathrm{P}_{\mathrm{p} 10}$ & $21,5 \pm 0,13$ & $82,9 \pm 1,06$ & $7,6 \pm 0,29$ & $32,6 \pm 2,13$ & $86,6 \pm 0,59$ & $8,7 \pm 0,16$ \\
\hline $\mathrm{P}_{\mathrm{p} 20}$ & $21,5 \pm 0,15$ & $82,4 \pm 1,23$ & $7,6 \pm 0,28$ & $31,4 \pm 0,97$ & $87,0 \pm 0,53$ & $8,6 \pm 0,21$ \\
\hline \multicolumn{7}{|l|}{ Molases } \\
\hline $\mathrm{P}_{\mathrm{m} 0}$ & $22,3 \pm 0,02$ & $83,4 \pm 1,11$ & $7,4 \pm 0,13$ & $36,5 \pm 0,32$ & $86,7 \pm 0,17$ & $8,3 \pm 0,10$ \\
\hline$P_{\mathrm{m} 10}$ & $21,3 \pm 0,18$ & $82,5 \pm 0,57$ & $7,4 \pm 0,21$ & $36,1 \pm 1,20$ & $87,0 \pm 0,30$ & $8,3 \pm 0,10$ \\
\hline $\mathrm{P}_{\mathrm{m} 20}$ & $21,3 \pm 0,06$ & $82,6 \pm 1,17$ & $7,8 \pm 0,39$ & $35,7 \pm 1,61$ & $87,1 \pm 0,16$ & $8,3 \pm 0,09$ \\
\hline \multicolumn{7}{|l|}{ Bekatul } \\
\hline $\mathrm{P}_{\mathrm{b} 0}$ & $22,1 \pm 1,25$ & $82,3 \pm 1,11$ & $7,0 \pm 0,08$ & $35,1 \pm 0,68$ & $87,5 \pm 0,73$ & $8,5 \pm 0,30$ \\
\hline $\mathrm{P}_{\mathrm{b} 10}$ & $21,4 \pm 0,07$ & $83,3 \pm 0,88$ & $7,2 \pm 0,15$ & $37,3 \pm 1,93$ & $86,2 \pm 1,17$ & $8,6 \pm 0,32$ \\
\hline $\mathrm{P}_{\mathrm{b} 20}$ & $21,3 \pm 0,01$ & $82,2 \pm 1,00$ & $7,4 \pm 0,06$ & $36,2 \pm 0,44$ & $86,7 \pm 0,46$ & $8,5 \pm 0,36$ \\
\hline \multirow{2}{*}{\multicolumn{7}{|c|}{$\begin{array}{l}\text { Tepung } \\
\text { Gaplek }\end{array}$}} \\
\hline & & & & & & \\
\hline $\mathrm{P}_{\mathrm{tg} 0}$ & $21,3 \pm 0,01$ & $83,0 \pm 1,15$ & $7,3 \pm 0,35$ & $34,0 \pm 0,27$ & $86,5 \pm 1,03$ & $8,5 \pm 0,13$ \\
\hline $\mathrm{P}_{\operatorname{tg} 10}$ & $21,3 \pm 0,11$ & $83,4 \pm 0,90$ & $7,3 \pm 0,68$ & $35,8 \pm 1,39$ & $87,2 \pm 1,01$ & $8,5 \pm 0,12$ \\
\hline $\mathrm{P}_{\mathrm{tg} 20}$ & $21,3 \pm 0,11$ & $82,7 \pm 0,55$ & $7,5 \pm 1,11$ & $36,6 \pm 1,61$ & $87,0 \pm 0,80$ & $8,5 \pm 0,10$ \\
\hline
\end{tabular}

Pembuatan silase pada dasarnya tidak bertujuan untuk meningkatkan kandungan nutrisi namun paling tidak mampu mengurangi jumlah nutrisi yang hilang selama ensilase berlangsung, namun penambahan bahan aditif berupa WSC berdasarkan Tabel 2 terbukti mampu meningkatkan kandungan BK, BO dan PK silase tebon jagung.Peningkatan kandungan nutrisi juga terjadi pada nilai BO dan PK dengan penambahan berbagai aditif dan level penggunaan sebelum ensilase ( 0 hari) dan setelah inkubasi (21 hari).

Data dalam Tabel 2. menunjukkan peningkatan kandungan BO antara 4,2\%$5,2 \%$ dan peningkatan kandungan $\mathrm{PK}$ antara 0,9-1,0\% dari silase tebon jagung sebelum dan sesudah ensilase 21 hari. Sartini (2003) menyatakan bahwa peningkatan protein kasar silase dipengaruhi oleh respirasi dan fermentasi. Respirasi akan menyebabkan kandungan nutrisi banyak yang terurai sehingga akan meningkatkan protein. Meningkatnya nilai protein silase juga dipengaruhi oleh adanya peningkatan nilai protein yang merupakan hasil dari fermentasi gula sederhana (Surono, dkk., 2006). Berdasarkan kandungan $\mathrm{BO}$ silase tebon jagung, penggunaan aditif pollard, molases dan tepung gaplek menunjukkan pengaruh yang paling baik dibansingkan dengan bekatul. Kandungan PK silase tebon jagung terbaik diantara seluruh perlakuan adalah pada penambahan $10 \%$ pollard. Peningkatan kandungan nutrisi dapat terjadi akibat adanya aktifitas bakteri saat proses ensiling berlangsung. Pemberian pollard akan meningkatkan BK, BO, PK, LK, dan TDN. Namun menurunkan kadar abu dan SK (Trisnadewi dkk., 2017). Pollard memiliki kandungan WSC 12,5\% sehingga penggunaan sebagai bahan tambahan cukup memenuhi kebutuhan karbohidrat terlarut pada pembuatan silase (Despal dkk., 2011). 


\section{KESIMPULAN}

Penambahan bahan aditif baik dalam bekatul, pollard, molases, dan tepung gaplek mampu meningkatkan kualitas silase tebon jagung dan perlakuan yang terbaik adalah penggunaan pollard dengan level optimal $10 \%$.

\section{DAFTAR PUSTAKA}

AOAC. (2005). Official Methods of Analysis.

Despal, D., Permana, I. G., Safarina, S. N., \& Tatra, A. J. (2011). Penggunaan berbagai sumber karbohidrat terlarut air untuk meningkatkan kualitas silase daun rami. Media Peternakan, 34(1), 69-76. https://doi.org/10.5398/med pet.2011.34.1.69

Hartutik. (2012). Metode Analisis Mutu Pakan. UB Press.

Hartutik, H., Fajri, A. I., \& Irsyammawati, A. (2018). Pengaruh penambahan pollard dan bekatul dalam pembuatan silase rumput odot (Pennisetum purpureum, Cv.Mott) terhadap kecernaan dan produksi gas secara in vitro. Jurnal Nutrisi Ternak Tropis, 1(1), 9-17. https://doi.org/10.21776/ ub.jnt.2018.001.01.2

Jasin, I. (2017). Pengaruh penambahan dedak padi dan inokulum bakteri asam laktat dari cairan rumen sapi peranakan ongole terhadap kandungan nutrisi silase rumput gajah. Jurnal Peternakan, 11(2), 59-63.

Riswandi. (2014). Kualitas silase eceng gondok (Eichhornia crassipes) dengan penambahan dedak halus dan ubi kayu. Jurnal Peternakan Sriwijaya, 3(1), 1-6. https://doi.org/10.33230/ JPS.3.1.2014.1726

Santi, R. K. D., Widyawati, W. P. S., \& Suprayogi. (2011). Kualitas dan nilai kecernaan in vitro silase batang pisang (Musa paradisiaca) dengan penambahan beberapa akselerator. Jurnal Tropical Animal Husbandry, 1(1), 15-23.

Soeharsono, \& Sudaryanto, B. (2006). Tebon jagung sebagai sumber hijauan pakan ternak strategis di lahan kering Kabupatn Gunung Kidul. In Loka Karya Nasional Jejaring Pengembangan Sistem Integrasi Jagung. Puslitbang Peternakan.

Sudarwati, H., Natsir, M., \& Nurgiartiningsih, V. (2019). Statistika dan Rancangan Percobaan Penerapan dalam Bidang Peternakan. UB Press.

Surono, M. S., \& Budhi, S. P. S. (2003). Kecernaan bahan kering dan bahan organik in vitro silase rumput gajah pada umur potong dan level aditif yang berbeda. J. Indon. Trop Anim. Agric, 1(1), 1-9.

Surono, Soejono, M., \& Budhi, S. P. (2006). Kehilangan bahan kering dan bahan organik silase rumput gajah pada umur potong dan level aditif yang berbeda. Jurnal. Indonesian Tropical Animal Agriculture, 31(1), 62-68.

Trisnadewi, A. A. A. S., Cakra, I. G. L. O., \& Suarna, I. W. (2017). Kandungan nutrisi silase jerami jagung melalui fermentasi pollard dan molases. Majalah Ilmiah Peternakan, 20(2), 55-59. https://doi.org/10.24843/MIP.2017.v2 0.i02.p03 